\title{
Runoff Voters Will Do the Darndest Things: An Analysis of the 2008 Georgia Democratic Senate Runoff
}

\author{
Scott E. Buchanan
}

Testing the frontrunner loses myth and minority loses myth, this paper examines the 2008 Georgia Democratic Senate runoff between Vernon Jones and Jim Martin. Despite winning 40 percent of the primary vote, Jones lost in the runoff to Jim Martin. Methods: We use a variety of data to determine what factors were having the greatest effect on the election. Results: Vernon Jones's strongest support came from the rural counties of central and southern Georgia. While Jones did win high levels of support in counties with large black populations, the fact that Jones was not performing as well in counties in metro Atlanta highlights that controversies surrounding Jones may have been playing a larger role than race. Conclusions: The lack of black voter turnout in the runoff illustrates the problems that even a black candidate has in motivating black voters to return for the runoff.

Runoffs are a feature of politics in eight states in the early 21 st century. As has been well documented by a variety of scholars, the runoff was implemented in the early 20th century during an age in which the Democratic Party so dominated the political scene that having the party primaries served the de facto role as an election since no organized Republican Party existed in these states. Despite the emergence of the GOP in the South during the 1960 s, the runoff continues to be utilized in some states, and runoffs are even used in municipal elections around the nation.

This paper seeks to use one contest, the 2008 Democratic primary and runoff in Georgia, as a test of two arguments put forward by Bullock and Johnson (1992) in their exhaustive research of runoffs in the United States. Specifically, this analysis will focus on the winner loses and minority loses myths regarding runoffs. Part of the reason for the specific analysis of this contest is that this contest featured a black primary winner who lost in a runoff. By examining the factors in play in these contests, we can expand our knowledge about the dynamics that are at work in runoffs which do not get as much scholarly attention as warranted. By studying further the forces at play, scholars, political consultants, and media pundits can have a greater understanding of what happens when candidates find themselves in the runoff. 


\section{Prior Research}

As Bullock and Johnson (1992) and Glaser (2006) point out, runoffs were instituted in a number of states in the early 20th century. In addition, a variety of municipalities around the nation utilize the runoff in deciding primary contest winners. Due to a controversial gubernatorial election in 1966, Georgia even goes to the extent of requiring a general election runoff if no candidate wins a majority of the vote in the general election. First used in 1992, Georgia Democrats reduced the threshold from 50 percent to 45 percent in the 1990 s, only to have Republicans increase it back to 50 percent in the early 21 st century.

The common theme in states that use the statewide runoff is that they are Southern states historically dominated by the Democratic Party. In most of these states, the Democratic primary was a multifactional affair (Black 1983). Given the fractious nature of the primaries, runoffs were established to require that the party nominee have at least 50 percent of the vote. Key (1949) states that runoffs also prevented a marginal, or extremist, candidate from cobbling together a coalition to win a plurality of the vote. During Key's day the fact that the Democratic Primary was equal to the general election meant the runoff was designed to ensure "mainstream" nominees.

While states that use the runoff today are no longer one-party areas, both parties continue to see value in the runoff. A variety of researchers have found that runoffs encouraged candidate involvement during the one-party era of Southern politics (Canon 1978; Wright and Riker 1989; Berry and Canon 1993). Even with the emergence of the Republican Party in the early 1990 s, the increased competitiveness of Southern primaries is still pronounced. Glaser (2006) finds that runoffs continue to encourage greater candidate competition in both the Democratic and Republican primaries than compared to the non-South in the two-party era. Much of the reason for this increased competition is that parties do not discourage candidates with divergent views from running based upon the assumption that the runoff will lead to a viable nominee. Obviously, the more candidates that qualify for an office greatly increase the likelihood of a runoff.

As one might expect, runoffs most frequently occur with high ticket offices like gubernatorial and U.S. Senate races. Engstrom and Engstrom (2008) find between 1980-2002 that runoffs were necessary to decide nearly 27 percent of all gubernatorial contests and 19 percent of all U.S. Senate contests in states requiring a majority vote. This is congruous with studies that found similar results in earlier time periods (Bullock and Johnson 1992). Runoffs for U.S. House elections and lower-level offices do not occur as frequently. At the local level however, Georgia election results show that runoffs are more likely for sheriff than any other local office (Bullock and 
Johnson 1992). Since sheriffs are considered the highest official of a county, this is consistent with a high profile office generating more candidates, and thus, a greater chance of a primary going into a runoff.

\section{Winner Loses Runoffs}

Another dynamic of the two-tiered primary and runoff is the possibility that the plurality primary winner does not always win the runoff. In fact, there is a perception that one wants to place second in the primary to have the best chance of winning the runoff. This "winner loses" belief is so engrained "among politicians and media pundits, that the candidates who tally the highest number of votes in the initial primary are doomed to defeat in the runoff" (Bullock and Johnson 1992, 27-28). This conventional wisdom is more myth than reality though. Key (1949) discovered that roughly 36 percent of all primary winners lose in a runoff, while Bullock and Johnson (1992) only find that it occurred in 30 percent of all runoffs from 1970-1986. More recently, Glaser (2006) observes that 28 percent of runoffs between 1980 and 2002 featured a second place primary finisher winning the runoff.

Part of the reason for the winner loses myth is that many of the examples of this phenomenon are high-profile statewide contests which attract more public attention. Throughout the history of the runoff a number of states have seen come from behind winners in the runoff whether it be Orval Faubus in 1954, George Wallace in 1970, or Sam Nunn in 1972. In all these cases though, the races were for gubernatorial or U.S. Senate races. Winner lose examples do exist at lower levels, but usually for U.S. House races.

Despite these notable examples, primary winners typically win their runoffs. Black and Black (1987) classify plurality primary winners into two categories: strong and weak frontrunners. Strong frontrunners are primary winners who garner at least 40 percent of the primary vote and defeated the second place finisher by at least 5 percentage points. Anything below this would constitute a weak frontrunner. Black and Black posit that strong frontrunners usually win their runoffs, while weak frontrunners are in more jeopardy. Engstrom and Engstrom (2008) find support for this thesis in runoffs between 1980 and 2002, with strong frontrunners winning 84 percent of runoffs during this period. Weak frontrunners won their runoffs in only 37 percent of the runoffs from this period.

While Black and Black were writing during a time that featured few Republican runoffs, one can discern a difference between the two parties in recent decades. Republican weak frontrunners had little chance in statewide runoffs, winning no gubernatorial primary runoffs and only 33 percent of U.S. Senate runoffs. Democratic weak frontrunners fared slightly better 
winning 37.5 percent of gubernatorial runoffs and 50 percent of U.S. Senate runoffs (Engstrom and Engstrom 2008).

A variety of reasons exist for why a primary winner would be at a disadvantage in a runoff. The most obvious is the second place finisher would be able to secure endorsements from other primary candidates and consolidate the support of rivals in order to win the runoff. In his analysis of Southern politics, Key (1949) states that the losing forces decide to throw their support behind the alternative candidate either because of fundamental disagreements with the primary winner or because of the unpopularity of the primary winner. In 1992, Paul Coverdell secured the endorsement of his Libertarian opponent from the Georgia U.S. Senate race and won the runoff over incumbent Wyche Fowler. In 2007, Paul Broun was able to secure the Republican nomination for Georgia's 10th Congressional District in the runoff due largely to primary winner Jim Whitehead's refusal to attend a runoff debate in Athens and because of the surfacing of controversial remarks that Whitehead made about the University of Georgia being a hotbed of liberalism (Pierce 2007).

Another argument is that voters make a conscious decision as to who would have the best chance of actually winning the general election. Bullock, Gaddie and Ferrington (2001) found in a study of U.S. House runoffs between 1988-1994 that political experience is not as large a factor as conventional wisdom holds. It may be that voters pay little experience to political experience at least in congressional runoffs. Bullock, Gaddie and Ferrington (2002) posit that runoff voters potentially are better informed in a two-man contest than in a larger primary field. Glaser (2006) finds evidence that come from behind runoff winners "are well positioned to win general elections" (786). Still, comparatively little research exists to answer the question of whether voters are making strategic decisions about candidate selection for the general election, although Niou (2001) finds that strategic voting is less likely to exist in a runoff than a primary.

\section{Racial Implications of the Runoff}

In the 1980s, the runoff became a source of controversy due to the argument that the runoff was preventing the nomination of black candidates, especially in statewide contests. Glaser (2006) argues that the runoff "helped to delay 'white flight' from the Democratic Party" (777). In the early 1960s and 1970s, some evidence that runoffs were damaging the electoral chances of black candidates did emerge. Most notably, in the late 1960s, eight black candidates won pluralities for legislative seats in Mississippi only for all eight to lose in runoffs against white candidates (Parker 1990). The idea that white voters could band together to defeat the electoral chances of a black 
candidate became so widespread that some blacks began to call this phenomenon "the runoff curse" (Patterson 1983, 239).

As is often the case with conventional wisdom, the argument that runoffs are anathema to black candidates is based largely upon perception and relatively little on actual fact. While some notable cases of runoffs harming the electoral chances of black candidates did exist in the late 1960s and early 1970s, Bullock and Johnson (1992) find runoffs actually helped black electoral chances more often than not. In 1970, segregationist exGovernor Orval Faubus of Arkansas lost in a runoff, while black Georgians and white moderates were able to rally behind George Busbee and defeat Lester Maddox's comeback bid in the 1974 Democratic runoff despite Maddox's plurality primary victory. Other examples exist from the 1970s of black voters rallying behind more progressive candidates in runoffs. Outside of the South, Bullock and Gaddie (1994) found that runoff requirements in Chicago city elections actually helped the electoral chances of both minority and female candidates.

In the 1980s, the runoff may have also helped to forestall the rise of the Republican Party in a number of Southern states because it allowed progressive white candidates, who overall were friendlier to black political concerns than more conservative white candidates may have been, to win offices. Without the runoff, it is possible that more black candidates would have won office by plurality margins, but White (1984) argues that it would have had the effect of driving more reactionary whites from the Democratic Party to the GOP. This view was commonly held among many political leaders of the 1980s, and little change occurred on the runoff front.

Since the early 1990s, the question of race and the runoff has largely disappeared for two reasons. First, the creation of a number of majorityblack districts in the South, both at the congressional level and state legislative level, led to a surge of black elected leaders. As a result, the runoff actually began to work to the benefit of black candidates, if a white candidate won a primary plurality. As an example, Alcee Hastings defeated a white candidate, Lois Frankel, in the 1992 runoff for Florida's 23rd Congressional District.

A second reason that the runoff became less controversial was due to a shift of support to the Republican Party. Beginning in the early 1990s, an increasing number of Southern whites began to align themselves with the GOP. This had the effect of making the Democratic Party "less white" and resulting in the nomination of more black candidates, especially in statewide contests. Both of these phenomena have led to the runoff's continued use and the loss of any racial stigma surrounding the runoff (Engstrom and Engstrom 2008). 


\section{Runoff Turnout}

A well-known feature of runoffs is their decline in turnout compared to the primary. Both Key (1949) and Ewing (1953) found that turnout declined between the primary and the runoff. Wright (1989) analyzes Democratic turnout in gubernatorial, U.S. Senate, and U.S. House races between 1956 to 1984. On average, turnout decreased between the primary and runoff, although great variation exists among the various states. Turnout drop-off was greatest in House and Senate runoffs, but not as great in gubernatorial primaries. As Republicans become a more viable alternative to the Democrats in the 1970s and 1980s, the stronger a Republican candidate in the general election, the more precipitous the decline in runoff turnout (Wright 1989). Engstrom and Engstrom (2008) find that turnout decreased in all but seven gubernatorial and U.S. Senate runoffs between 1980 and 2002, which accounted for 13.5 percent of all runoffs during this period. Runoffs turnout is highest in gubernatorial runoffs.

With its unique general election runoff, Georgia has had a second round to the general election for a variety of offices. In all cases, turnout for the general election runoffs declined from the general election. Generally speaking, statewide contests drew more turnout than did the few examples of local elections that ended in a runoff. The first general election runoff in state history took place in 1992 between Wyche Fowler and Paul Coverdell. As a testament to the drop-off effect in runoffs, the total runoff vote for both candidates was only slightly higher than the number of votes garnered by Fowler, the general election plurality winner, in the first round of the election.

Bullock, Gaddie and Ferrington (2002) argue that runoff turnout is a more complex phenomenon in their analysis of runoffs from 1982-1996. Not surprisingly, the quality of runoff candidates help to stimulate greater turnout as did the amount of money spent on campaigning. The interval between the primary and runoff also played a factor, with turnout seeming to peak with a three week interval between the two contests. Perhaps most interestingly, Bullock et al. (2002) find that little carryover effect from the primary to the runoff in terms of campaign spending, leading the authors to the conclusion that the runoff is "a new game, a new campaign, affected largely by the factors endogenous to that event" (1222).

\section{Georgia Senate Runoff}

As mentioned previously, the 2008 Georgia Senate runoff provides an example of both the winner loses and minority loses aspects discussed by Bullock and Johnson. This was not the first white/black runoff in recent 
Georgia political history. In 1990, Zell Miller faced Andrew Young in the Democratic runoff for governor. However, the Jones/Martin runoff was the first time that a black candidate was the frontrunner heading into the runoff. Five Georgia Democrats sought their party's nomination in 2008 to oppose Republican Saxby Chambliss's reelection bid. From this group, two candidates, Vernon Jones and Jim Martin, were the clear frontrunners throughout the primary campaign season. Jones was the CEO of DeKalb County, while Jim Martin was a former member of the Georgia House of Representatives. While Jones had never run for statewide office, Martin was the Democratic nominee for Lt. Governor in 2006, losing to Casey Cagle.

Both Jones and Martin spent much time attacking and criticizing one another during the lead-up to the Democratic Primary. Jones ran as a moderate-to-conservative Democrat who often criticized his opponent as "too liberal" for Georgia and stated that the Georgia Democratic Party had fallen into a habit of nominating "losers" for office (Smith 2008). Jim Martin constantly criticized Jones's admission that he had voted for George W. Bush in 2000 and 2004. To some degree, national issues, such as the economy and Iraq, took more of a front-seat than did state issues.

One of the biggest issues in the campaign was Jones himself. Over his tenure as DeKalb County CEO, Jones had been involved in several highprofile controversies with allegations that he had harassed one constituent and allegedly shoved a DeKalb County Commissioner who disagreed with Jones on an issue. Jones had also made enemies among the DeKalb police force by his hiring of the former police chief of Dallas, Texas who had faced criticism over his poor management of the department. In addition, Jones had faced a rape charge in 2005 which was eventually withdrawn by the accuser. While Jones maintained the relationship was consensual, the unnamed woman did not recant her story. All of these incidents certainly cast a pall over Jones's candidacy heading into the primary.

As pundits expected, Jones and Martin found themselves in a runoff after the July 15, 2008 primary. Jones won 40.4 percent of the statewide vote, while Martin won 34.4 percent. As required by Georgia law, a runoff between Jones and Martin was held three weeks later on August 5, 2008. During the three weeks of the runoff campaign, both men tried to position themselves as the candidate most likely to defeat Saxby Chambliss in November. Martin continued to position himself as the liberal in the race, arguing that the United States should withdraw from Iraq as quickly as possible, while Jones continued to run as a moderate. In an appeal to black support, Jones began reminding voters that Martin, a John Edwards supporter, had not supported Barack Obama in the presidential primary.

In the runoff, Martin emerged the victor with 59.9 percent of the vote despite coming in second in the primary. As usual, voter turnout was lower 
in the runoff with roughly 319,000 votes cast as opposed to approximately 493,000 in the primary. While it is possible to argue simply that Martin's supporters turned out in greater numbers, it is also worth examining this contest to determine if other factors were at work. We now analyze the runoff between Jones and Martin to see what accounts for this reversal of positions for the two candidates.

\section{Data and Method}

Given the fact that the Jones/Martin runoff featured a black candidate and white candidate, there is a possibility that race played a role in the contests. This is even more likely given that the white candidate, Martin, came from behind to win the runoff. As a result, this analysis will attempt to determine the role that race might have played in the runoff. Hypotheses, about what factors were playing a role in the Jones/Martin contest, are tested in two different models with Vernon Jones's percentage of the primary vote in the first model, Jones's percentage of the runoff vote in the second model. ${ }^{1}$ Election figures are readily available through Elections Division of the Georgia Secretary of State's website (http://sos.georgia.gov/Elections/).

The level of analysis is at the county-level. While it is an ecological fallacy to use aggregate-level data to predict individual behavior, the data can allow us to see patterns that emerge in each candidate's support. From there inferences may be drawn as to the role that race may have been playing. The definition and measurement of the independent variables are as follows. In all cases the variables are derived from data found in the 2000 Census. While the primary and runoff took place in 2008, population estimates for 2008 do not contain actual data for any demographic variables, except the black population. As a result, the actual data from 2000 is more appropriate than combining one 2008 estimate model with all other variables based upon older data.

Education: Education can affect voting behavior (Wolfinger and Rosenstone 1980; Miller and Shanks 1996). In addition, Giles and Buckner (1995) found that lower levels of education among white voters plays a role in the likelihood of racially influenced voting. Education is operationalized as two separate variables: the percentage of citizens with a high school education and the percentage of citizens with a college degree.

Black Population: Counties with higher black populations would be expected to give greater support to a black candidate. The black population variable is coded as a percentage of a county's that consists of black citizens.

Senior Citizen Population: This variable is simply the percentage of a county's population that is 65 years of age or older. In order to discern patterns among this age cohort by race, this variable is two separate variables 
Table 1. Descriptive Statistics

\begin{tabular}{lcc}
\hline & Mean & Std \\
\hline Black Senior Citizen Percentage & 2.5 & 2.1 \\
White Senior Citizen Percentage & 8.9 & 3.2 \\
Black Percentage & 28.0 & 17.0 \\
High School Percentage & 70.7 & 7.6 \\
College Percentage & 14.0 & 7.2 \\
Black Turnout & 16.5 & 16.7 \\
White Turnout & 21.2 & 19.7
\end{tabular}

Note: The dichotomous Atlanta DMA variable was coded in 33 percent of cases, while the local runoff variable was codes in 28 percent of cases.

based upon the percentage of white and black residents over the age of 65 in a given county.

Demographic Turnout: Two variables representing turnout by race are included in the model for the primary. Demographic turnout data for the primary is available from the Georgia Secretary of State. These turnout figures will give some indication of the strengths and weakness of the Jones's vote.

Atlanta DMA: This is a dichotomous control variable for the counties falling into the Atlanta television market. There are a total of 52 Georgia counties in the Atlanta designated market area (DMA). Since Jones was frequently covered by Atlanta television outlets, a broader net is cast here than a strictly urban/rural split or the 28 counties designated as metropolitan Atlanta by the Census Bureau. There is no reason to believe that any tangible urban/rural split is occurring in this contest. However, it is conceivable that voters in the Atlanta DMA were much more familiar with Jones, and the controversy surrounding him, than other parts of the state. As a result, all counties in the Atlanta DMA are coded as 1 and the state's other 107 counties are coded as 0 .

Local Runoffs: This is another dichotomous control variable utilized only in the second model analyzing the runoff between Jones and Martin. This variable is included to test for local forces that might spur runoff turnout in some counties around the state. This variable is coded 1 if there was another Democratic runoff for a lower-level office. Forty-five counties had local runoffs simultaneous with the Senate runoff in 2008.

Turnout by demographics reveals a familiar pattern in Georgia Democratic politics with black participation the highest followed by white voters. 
The large standard deviations gave an indication of the differing demographics of Georgians in urban/suburban counties versus rural counties with great variation existing with the education and black population variables, while senior citizens are relatively well-distributed amongst Georgia counties. Correlations revealed no multicollinearity problems.

\section{Analysis}

If race was playing a role in the primary, Vernon Jones would be stronger in counties with higher black populations, while he might not do as well among counties with higher numbers of white voters. Figure 1 illustrates the counties where Jones either won an outright majority or plurality of the vote. Table 2 shows the results of the model testing Jones's primary performance.

The model explains 72 percent of the variance with four variables attaining statistical significance. The most significant variable is the black percentage of a county's population with a .63 relationship. These results certainly indicate that Jones was stronger in counties where black populations were a larger proportion of the population. As the attached figure indicates, many of these counties were in the black belt counties of central and southwest Georgia. In addition, counties with higher concentrations of white senior citizens had a negative effect on the Jones's vote. An analysis of the county-level returns reveals the following general pattern: the concentration of senior citizens tends to be the heaviest in either poor, rural counties, or counties of northeast Georgia. The former category of counties also has predominately white populations which were not Jones strongholds. Both educational variables were significant in the expected directions: the high school variable had a positive relationship with the Jones vote, while the college variable was negative.

Both turnout variables are statistically significant with the Jones vote. The white turnout variable was negative with the Jones vote, while the black turnout figure was positive. This finding underscores that Jones was certainly not the favored candidate of many white voters in counties that had high levels of white turnout, which are counties that generally are rural counties with high black populations. This fact is indicative of the possibility of racially motivated voting. The fact that the relationship between black turnout and Jones's vote is not greater than it is though underscores Jones's problems in the primary and potential trouble for the runoff.

The black senior citizen variable was statistically insignificant, although the relationship was in the expected direction. Relatively speaking, white senior citizens outnumbered black senior citizens in the majority of the state's counties possibly explaining the lack of any statistically significant relationship. The Atlanta DMA control variable was not significant either. 
Figure 1. Counties Won by Vernon Jones in the Primary

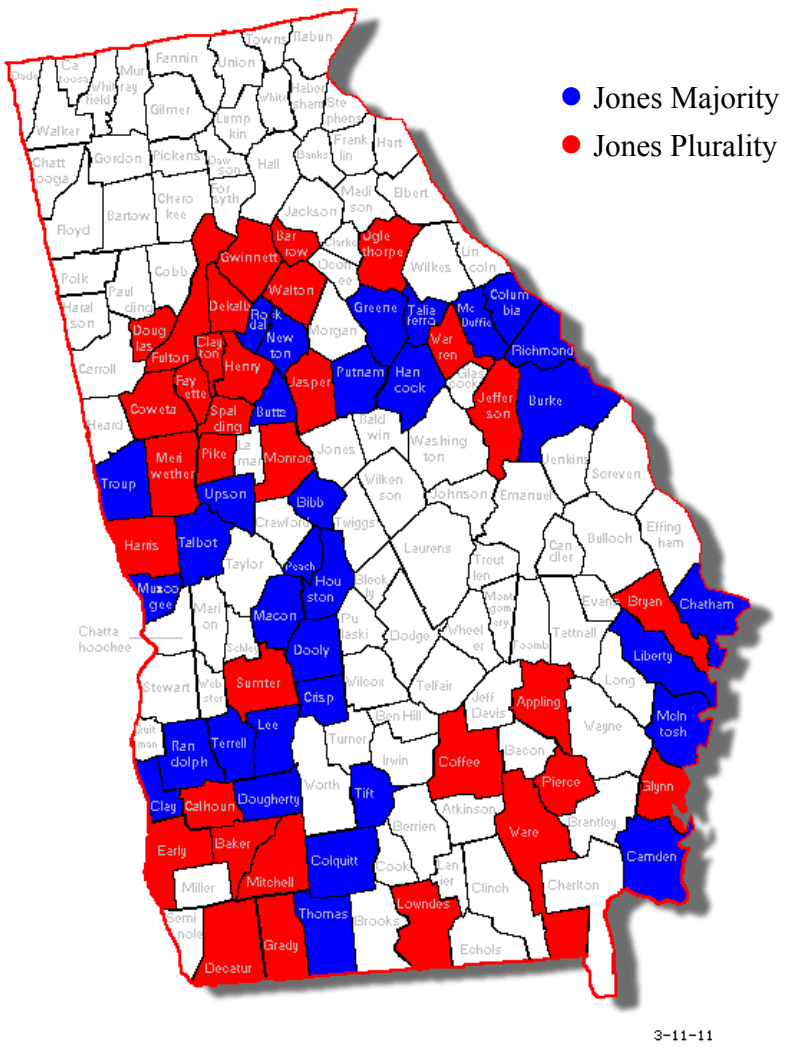

Table 2. Jones's Primary Percentage Vote

\begin{tabular}{lcl}
\hline & $\mathrm{b}$ & s.e. \\
\hline Black Senior Citizen Percentage & 1.01 & .70 \\
White Senior Citizen Percentage & -.50 & $.24^{*}$ \\
Black Percentage & .63 & $.08^{* * *}$ \\
High School Percentage & .43 & $.17^{* *}$ \\
College Percentage & -.36 & $.16^{* *}$ \\
Black Primary Turnout & .32 & $.09^{* * *}$ \\
White Primary Turnout & -.61 & $.07^{* * *}$ \\
Atlanta DMA & -1.93 & 1.71 \\
Constant & -.56 & 11.58 \\
Adjusted $\mathrm{R}^{2}=.72$ & & \\
$\mathrm{~N}=159$ & & \\
$* \mathrm{p}<.05 ; * * \mathrm{p}<.01 ; * * * \mathrm{p}<.001$ & & \\
\hline
\end{tabular}


Next, Jones's performance in the Democratic runoff is analyzed. The same socioeconomic variables are used in the runoff model. The Atlanta DMA variable is included again as well as a dichotomous variable denoting whether a county featured a Democratic runoff of lower level offices as well. Due to a lack of racial turnout data, the demographic variables are excluded from the model. ${ }^{2}$ Figure 2 demonstrates the counties which Jones won in the runoff, while Table 3 presents the relationships of the independent variables with the dependent variable, Vernon Jones's runoff percentage.

With an adjusted $\mathrm{R}^{2}$ of .64 , six of the seven variables have statistically significant relationships with Jones's runoff vote. The most statistically significant relationship was the Atlanta DMA variable with a very negative effect at -11.5 on the dependent variable. Quite obviously, Jones was having serious problems in counties closer to Atlanta. Clearly, Jones's past political experience was not a help to him. The very negative association is likely a consequence of the negative media coverage of Jones in the Atlanta television market. Outside of the Atlanta area though, media coverage from smaller television markets was not nearly as great to the point of being nonexistent in some markets. In addition, the de facto newspaper for the state, The Atlanta Journal-Constitution, had reduced its circulation to the counties of the Atlanta DMA by 2008. Thus, voters further from Atlanta were less likely to influenced by media coverage of controversies involving Jones.

The local runoff control variable had a -9.6 relationship with Jones runoff vote. This variable was designed to determine if local-level offices in the runoff could have been driving turnout and in what direction. Clearly, Jones was faring very poorly in those counties that had local runoffs in play. Part of the explanation for this relationship could be that voters coming back for the runoff were better informed voters who might possibly be more familiar with Jones's scandals. These scandals could have been sufficient to lead voters to cast a ballot for Martin. Some research indicates that scandals can outweigh other concerns that voters might have when casting a ballot (see especially Bauer and Hibbing 1989).

Like the primary model, both education variables were statistically significant but in opposite directions. Jones performed better in counties with larger concentrations of high school graduates. Give that rural counties have higher numbers of residents with only a high school diploma, this finding is not surprising in light of the other variables in play. Conversely, Jones fared poorly with counties with high numbers of college graduates. Much of this negative association can be attributed to Jones's unpopularity in metro Atlanta and higher concentrations of college graduates are in the Atlanta DMA.

In the runoff, Jones had significant problems with counties that had higher percentages of white senior citizens. Examining the election returns, 
Figure 2. Counties Won by Vernon Jones in the Runoff

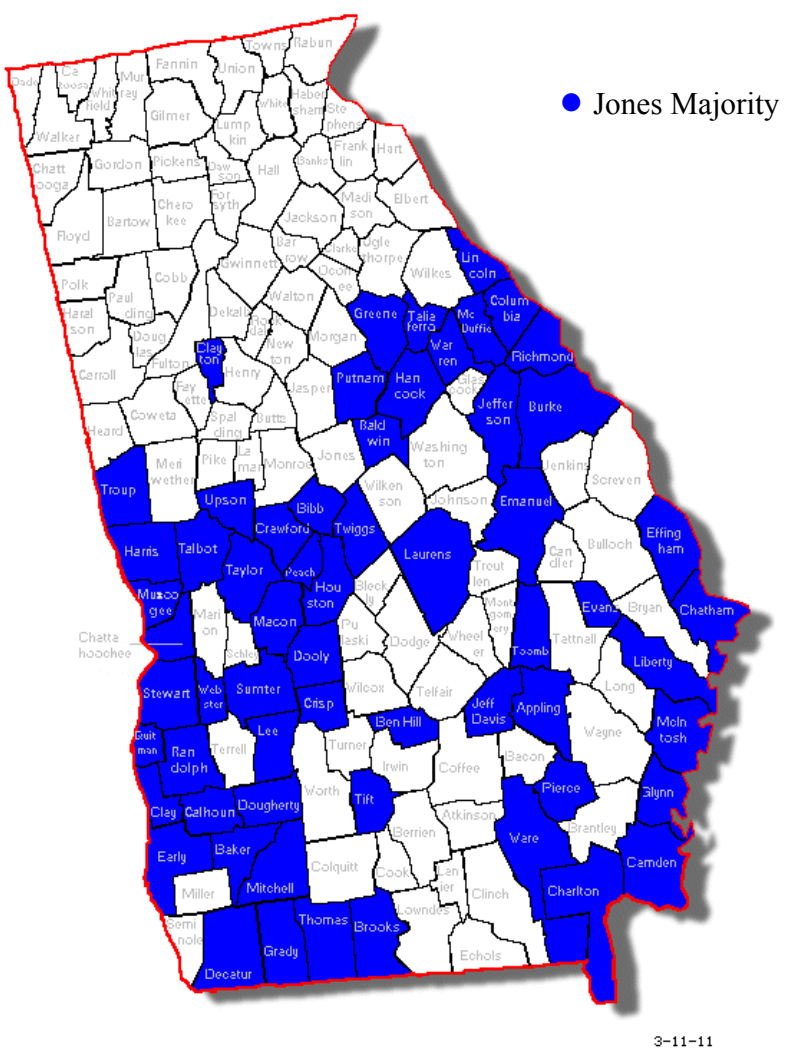

Table 3. Jones's Runoff Percentage Vote

\begin{tabular}{lcc}
\hline & $\mathrm{b}$ & \multicolumn{1}{c}{ s.e. } \\
\hline Black Senior Citizen Percentage & 1.45 & .93 \\
White Senior Citizen Percentage & -1.01 & $.32^{* *}$ \\
Black Percentage & .47 & $.11^{* * *}$ \\
High School Percentage & .78 & $.22^{* * *}$ \\
College Percentage & -.81 & $.21^{* * *}$ \\
Atlanta DMA & -11.54 & $2.20^{* * *}$ \\
Local Runoffs & -.9 .64 & $1.99^{* * *}$ \\
Constant & -.95 & 14.88 \\
Adjusted $\mathrm{R}^{2}=.64$ & & \\
$\mathrm{~N}=159$ & & \\
$* \mathrm{p}<.05 ; * * \mathrm{p}<.01 ; * * * \mathrm{p}<.001$ & & \\
\hline
\end{tabular}


Jones did poorly in the counties of northeast Georgia that had high numbers of white senior citizens, and this was combined with Jones's weakness he had in the area during the primary. Again, given that these counties have higher white populations, race could have been playing a role as well. Like the primary model, the black senior citizen variable was statistically insignificant.

Jones performed his best among the counties that contained higher black populations. Clearly, Jones's base of support was black voters as evidenced by the fact that he carried all but two counties that had a black county population greater than 50 percent. Alternatively, Jones fared poorly in counties that had less than a 20 percent black population.

\section{Conclusions}

Contrary to the frontrunner and minority loses myths, the 2008 Georgia Democratic runoff featured the come-from-behind-win of Jim Martin over Vernon Jones. Although Jones was the frontrunner in the primary, troubling issues from his primary victory were evident. Foremost among those concerns was that Jones was unable to win many counties in the Atlanta area, where his name was familiar among voters. Unfortunately for Jones, his name had negative connotations due to the notoriety surrounding him. Jones performed better among the heavily black counties of central and south Georgia, while Jim Martin won the suburban and urban counties of the state.

Despite being a frontrunner, Jones was simply saddled with too much controversy to increase his support between the primary and runoff. Rather than voters deciding to consolidate their support behind Martin, Jones reached a ceiling that he could not break. When scandals surround a candidate in a primary, it is quite possible that those controversies are so debilitating to trump the fact that primary frontrunners normally win their runoff contests.

This analysis also seeks to explore this contest from the minority loses myth as well. While demographic turnout data was only available for the primary, counties with high levels of white turnout generally were not helpful to Vernon Jones. Counties with high concentrations of white senior citizens were strongly negative towards Jones as well. Still, no evidence suggests that any type of white racial backlash worked against Jones. Instead, a voter mobilization dynamic was most likely at work. Counties with larger white populations had relatively little falloff between the primary and runoff. Turnout in counties with larger black populations were another story though. Quite simply, those counties had much greater decreases in voter turnout suggesting that black voters chose to stay at home for the runoff even with a black candidate in the runoff. Figure 3 demonstrates the counties with the 
Figure 3. Voter Turnout Decline Between Primary and Runoff

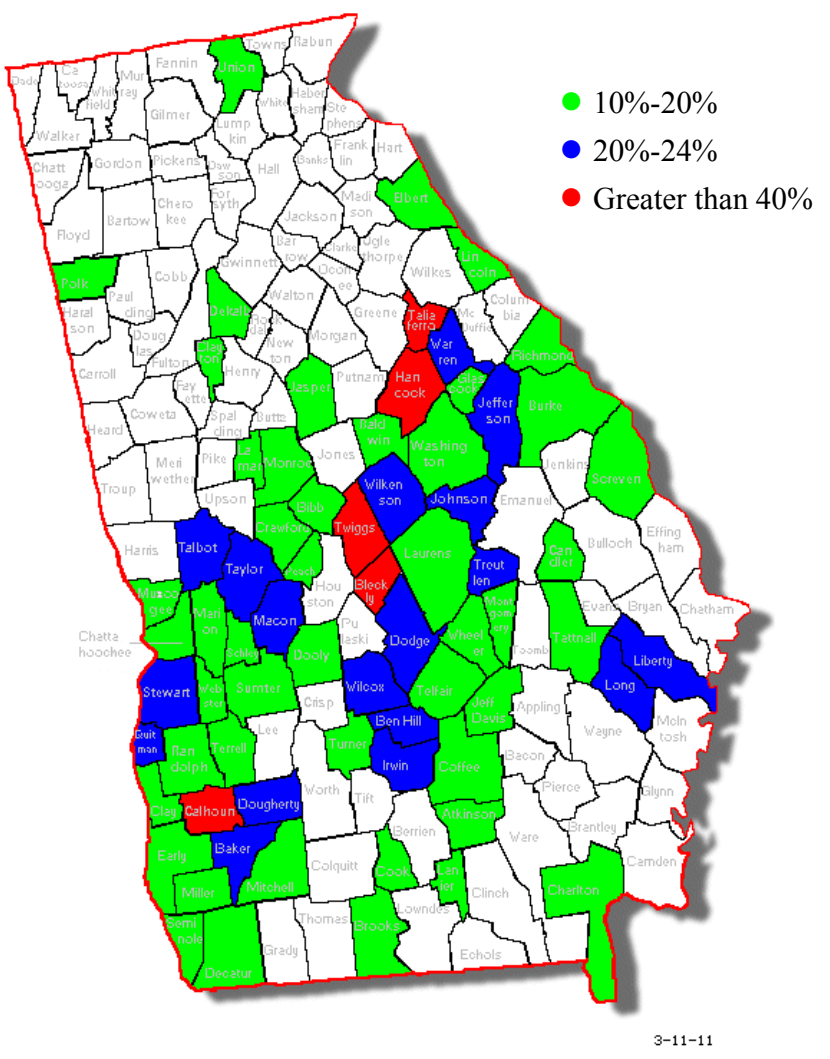

largest declines in turnout between the primary and runoff. Most of these counties were those that Jones had either won outright or by a plurality in the primary.

All but fourteen counties had a decrease in runoff turnout. In all cases, those counties that had an increase in turnout featured hotly contested local contests. Unfortunately for Jones, the counties with biggest drop-off in the runoff turnout were rural counties of central and south Georgia with the highest decline in counties with high black populations. While the number of counties won by Jones actually increased in the runoff, it was not enough to counter the much higher turnout in the majority white counties compared to the overwhelmingly black counties.

While this drop in runoff turnout is nothing new in Georgia politics, what is significant here is that the majority of previous statewide runoffs featured two white candidates. While black voters traditionally have not 
turned out in large for runoffs, this runoff, as well as the 1990 runoff between Zell Miller and Andrew Young, suggest that turnout among black voters will still decline even with a black candidate in the mix, even when a black candidate is the primary frontrunner. This fact alone illustrates the problems with runoff turnout among black voters when a black candidate is involved in the contest, even as the plurality winner of the primary. It should also serve as a cautionary note on the lack of turnout in general for runoffs in other southern states.

\section{NOTES}

${ }^{1}$ Initially, a third model using the difference between Vernon Jones vote in the primary and runoff as the dependent variable was tested. However, heteroskedascity existed in that model. After performing WLS on the offending variable, no variables achieved statistical significance. Heteroskedascity was not present in either models 1 or 2.

${ }^{2}$ The Georgia Elections Division does not compile racial turnout in either the primary runoff or general election runoff.

\section{REFERENCES}

Bauer, Monica, and John R. Hibbing. 1989. Which Incumbents Lose in House Elections: A Response to Jacobson's 'The Marginals Never Vanished.' American Journal of Political Science 33(1):262-271.

Berry, William D., and Bradley C. Canon. 1993. Explaining the Competitiveness of Gubernatorial Primaries. Journal of Politics 55(2):454-471.

Black, Earl. 1983. A Theory of Southern Factionalism. Journal of Politics 45(3):594-614.

Black, Earl, and Merle Black. 1987. Politics and Society in the South. Cambridge, MA: Harvard University Press.

Bullock, Charles S., and Loch K. Johnson. 1992. Runoff Elections in the United States. Chapel Hill: The University of North Carolina Press.

Bullock, Charles S., and Ronald Keith Gaddie. 1994. Runoffs in Jesse Jackson's Backyard. Social Science Quarterly 75(3):446-454.

Bullock, Charles S., Ronald Keith Gaddie, and Anders Ferrington. 2001. When Experience Fails: The Experience Factor in Congressional Runoffs. Legislative Studies Quarterly 26(1):31-43.

Bullock, Charles S., Ronald Keith Gaddie, and Anders Ferrington. 2002. System Structure, Campaign Stimuli, and Voter Falloff. Journal of Politics 64(4):1210-1224.

Canon, Bradley C. 1978. "Factionalism in the South: A Test of Theory and a Revisitation of V.O. Key. American Journal of Political Science 22(4):833-848.

Engstrom, Richard L., and Richard N. Engstrom. 2008. The Majority Vote Rule and Runoff Primaries in the United States. Electoral Studies 27(3):407-416.

Ewing, Cortez A.M. 1953. Primary Elections in the South. Norman: University of Oklahoma Press.

Giles, Michael W., and Melanie Buckner. 1995. David Duke and the Electoral Politics of Racial Threat. In David Duke and the Politics of Race in the South, eds. John C. 
Kuzenski, Charles S. Bullock, III, and Ronald Keith Gaddie. Nashville, TN: Vanderbilt University Press.

Glaser, James M. 2006. The Primary Runoff as a Remnant of the Old South. Electoral Studies 25(4):776-790.

Key, V.O. 1949. Southern Politics in State and Nation. New York: Alfred A. Knopf.

Miller, Warren E., and J. Merrill Shanks. 1996. The New American Voter. Cambridge, MA: Harvard University Press.

Niou, Emerson M.S. 2001. Strategic Voting under Plurality and Runoff Rules. Journal of Theoretical Politics. 13(2):209-227.

Parker, Frank R. 1990. Black Votes County: Political Empowerment in Mississippi after 1965. Chapel Hill: University of North Carolina Press.

Patterson, Beeman C. 1983. The Three Rs Revisited: Redistricting, Race, and Representation in North Carolina. Phylon 44(3):232-243.

Pierce, Greg. 2007. Inside Politics. Washington Times. July 24, p. A6.

Smith, Ben. 2008. Vernon Jones Comes Out Swinging Against 'Loser' Democrats. Atlanta Journal-Constitution. 30 April 2008, 1A.

White, Theodore. 1984. Jackson, Democratic Revolutionary. New York Times. April 5, p. 1 A.

Wolfinger, Raymond E., and Steven J. Rosenstone. 1980. Who Votes? New Haven, CT: Yale University Press.

Wright, Stephen G. 1989. Voter Turnout in Runoff Elections. Journal of Politics 51(2): 385-396.

Wright, Stephen G., and William H. Riker. 1989. Plurality and Runoff Systems and Numbers of Candidates. Public Choice 60(2):155-175. 